\title{
ART PUZZLING WAR IN ANTHONY DOERR'S ALL THE LIGHT WE CANNOT SEE
}

\begin{abstract}
Anthony Doerr's novel All the Light We Cannot See presents the story of two children, a blind French girl and an orphan German boy, within a belligerent context. The author creates the perfect frame for various intersections: past and present intermingle in the form of the narrative, through regularly sliding planes, as well as in the characters' minds. The novel is rigorously and artfully designed like a puzzle, similar to the ones the locksmith, the girl's father, builds for his daughter, which turns the reading into an adventurous reconstruction of the story. The paper presents the narrative techniques the novelist uses to bring together the aspects mentioned above and to show how art can influence the characters' decisions and behaviour.
\end{abstract}

Key words: American literature, war, memories, narrative techniques, puzzle

We live through life, but we live through art, too. And in art, as in life, nothing is generalized. No one thing is a copy of the next. Everything is individual.

(Doerr 2011: 302)

War has always been a source of inspiration for artists, because of its dramatism, terror and contrasts which need reconciliation. Researchers and writers have explored various forms of war representation and of aspects related to war eventually focusing on the context, the memories and the reconciliation of different war-related elements (Lamberti and Fortunati 2009). Art on war is a way to estheticise the latter, to beautify terror, to make it spectacular, to render it harmonious despite its horrors. Can art thus 'degrade' war? What can readers understand of the wittily orchestrated aspects of war? Heaney's poem "The Settle Bed" has often been used as an example for the relation between history and the present, between war and art, showing how the past can be reimagined and accommodated by the present, how it can be made to answer the needs of the present generation. "Whatever is given can always be reimagined, however foursquare,/ Plank-thick, hull-stupid and out of its time/ It happens to be" (Heaney 1999:

*Faculty of Letters, University of Craiova, 13 A. I. Cuza, 200585 Craiova, Romania; e-mail: florianghel1@ yahoo.com 
321). As he states in "The Redress of Poetry", poetry, therefore art, can counterweight or balance or redress reality in order to reach what he calls, referring to Simone Weil's Gravity and Grace, "some transcendent equilibrium" (Heaney 1995: 15). As Danchev synthesized, "poetry - art - can function as a kind of moral spirit level, an agent of equilibration" (Danchev 2009: 1) or "an upright, resistant, and self-bracing entity within the general flux and flex" (Heaney 1995: 15). Writing about Heaney's above mentioned poem, Murphy admits "that one of the enduring values of Heaney's poetry has been his willingness to imagine unexpected destinations for the hull-stupid ship of history" (Murphy 2009: 120).

Similarly, Anthony Doerr, who majored in history, re-imagines war in his novel All the Light We Cannot See and embellishes it with magic. The action unfolds during World War II and shifts the reader from one place to another around Europe, especially France and Germany, while gradually building a counterbalancing path through war and life generated by art. On the one hand the novel has a puzzling structure due to its frequent shifts in time and space, from the characters' present to their past. This structure is rendered into units of text as separate items and shifts are announced or suggested in titles, which provides the reader with useful guidance in assembling the pieces of the puzzle. The first chapter entitled "Zero" is also dated 7 August 1944 and contains the following subchapters: "Leaflets", "Bombers", "The Girl", "The Boy", "Saint-Malo", "Number 4 Vauborel", "Cellar", "Bombs Away". It presents the reader with the context - opening in the middle of the events, protagonists, key places on the map of the narrative assigned to 1944. The second chapter entitled "One" is set in 1934, ten years earlier, and refers to other spaces which represent the titles of several subchapters like: "Muséum National d'Histoire Naturelle", "Zollverein", "Take Us Home". Other motifs of the novel are used as peritexts and can be seen as a synthesis of the subordinate texts: "Radio", "Light", "The Sea of Flames", "The principles of Mechanics", etc. This explicit fragmentary structure is additional to other inner anachronies that contribute to the authenticity of the narrative flow.

On the other hand, the way in which characters are connected to art determines their evolution within the larger belligerent context. Subscribing to Doerr's essay on the individual experience with the book one is reading, which aims at establishing a relation between art and life, I can say that the novel All the Light We Cannot See is an unexpected and intelligent combination of contradictory elements related to time, to reality and fiction/art, and to different identities contextually shaped. The orchestration of these elements leads to the idea that art, with a focus on music and fiction in this case, contributes to the succession of the events and to the conclusion of the conflict, being an engine for the characters and for the novel. Doerr impersonates his belief in the individual's formation through reading books and listening to music by creating 
the two protagonists of the novel who remain attached to several good memories of the past related to art, memories that are retained for their stimulating effect.

Though generally in psychology, starting with Sigmund Freud's analysis and theories concerning childhood memories, such as Psychopathology of Everyday Life, the focus is on the traumatic effect childhood memories can have upon people and on the obsessive return of traumatic past experiences, there are situations when happy moments, also childhood memories, become stimuli for people, helping them to cope with present hardships and guiding them through life. New research in psychology has demonstrated that good childhood memories lead to "adaptive development and adjustment in adolescence and young adulthood" and may provide good health (Chopick and Edelstein 2019: 84). Thus, memories can act so as to counterweight the present situation and create an equilibrium, in the same way art succeeds in grasping the "terrible beauty", as Yeats calls it in his poem Easter Rising 1916, of a battle or a war.

Doerr's novel is a proof of the role art has for the protagonists, to teach and to delight them, and also an example of how defense mechanisms may act to ensure their surviving during the war. For instance, a form of regression can be identified in the characters' need to return to their childhood memories or life is understood and tailored through their readings or childhood stories in a form of sublimation.

The novel begins with Saint-Malo being bombarded in 1944, the zero moment, with lapidary notes on the setting and short introductions of the two protagonists, Marie Laure - a French blind girl and Werner Pfennig - a German boy, living this experience in opposite camps. Bewilderment and suspense are created through these flashes of information, apparently not related to each other. It is this disconnectedness that becomes an incentive for the reader to imagine that the fragmentary structure and the different plot lines will converge, solving the initial puzzle in terms of form. The narrative moves on more planes - the girl's story, the boy's and the story of the Sea of Flame in alternation. There is also a movement from the past to the present at a faster pace, covering more years ("One 1934", "Three June 1940", etc.) which alternates with a much slower advance in the 1944 bombardment of Saint-Malo which is rendered through daily account ("Zero 7 August 1944", "Two 8 August 1944", etc.). All the lines converge to the meeting of Marie-Laure and Werner when the contrast between the accelerated succession of the past events and the suspended and almost paralyzing situation of the two protagonists entrapped in enclosed spaces (a cellar and uncle Etienne's house) in Saint-Malo is cancelled. These oscillations between past and present, between a fast and a slow rhythm are completed with the oscillation between art and reality.

Marie-Laure LeBlanc is the courageous daughter of the locksmith of the Museum of Natural History in Paris. She has learned to manage by herself on the streets in her district due to a model of it made of wood by her father. Monsieur LeBlanc is 
thus the artisan that makes a "copy" of the world to help his daughter understand it. His models are instruments that help them cross each other's worlds, and help her develop other skills for orientation in space: thinking and the senses which she will efficiently use later in Saint-Malo during the war. Each short sequence reveals details in her life which initially illicit emotion in the reader, but later turn out to contribute to her development. Marie-Laure's senses and mind are stubbornly and meticulously sharpened by her father who also cultivates her interest in marine specimens and in adventure books like Jules Verne's Twenty Thousand Leagues Under the Sea.

Her memory is improved as she has to remember space expressed in the number of steps.

Usually Marie-Laure can solve the wooden puzzle boxes her father creates for her birthdays. Often they are shaped like houses and contain some hidden trinket. Opening them involves a cunning series of steps: find a seam with your fingernails, slide the bottom to the right, detach a side rail, remove a hidden key from inside the rail, unlock the top, and discover a bracelet inside.

For her seventh birthday, a tiny wooden chalet stands in the center of the kitchen table where the sugar bowl ought to be. She slides a hidden drawer out of the base, finds a hidden compartment beneath the drawer, takes out a wooden key, and slots the key inside the chimney. Inside waits a square of Swiss chocolate.

"Four minutes," says her father, laughing. "I'll have to work harder next year." (Doerr 2014: 35)

Hearing can help her appreciate the distance and smells outline the identity of places and the time of the year.

For a long time, though, unlike his puzzle boxes, his model of their neighborhood makes little sense to her. It is not like the real world. The miniature intersection of rue de Mirbel and rue Monge, for example, just a block from their apartment, is nothing like the real intersection. The real one presents an amphitheater of noise and fragrance: in the fall it smells of traffic and castor oil, bread from the bakery, camphor from Avent's pharmacy, delphiniums and sweet peas and roses from the flower stand. On winter days it swims with the odor of roasting chestnuts; on summer evenings it becomes slow and drowsy, full of sleepy conversations and the scraping of heavy iron chairs. 
But her father's model of the same intersection smells only of dried glue and sawdust. Its streets are empty, its pavements static; to her fingers, it serves as little more than a tiny and insufficient facsimile. He persists in asking Marie-Laure to run her fingers over it, to recognize different houses, the angles of streets. (Doerr 2014: 35)

Imagination is developed as she has to represent the stories she reads in her mind based on limited images from the real world. Courage and a sense of adventure or a thirst for knowledge and discovery are instilled due to Jules Verne's novels. A sense of loyalty that makes her help the locals of Saint-Malo during the war may be the result of her having read The Three Musketeers. She has the profile of a hero borrowed from her readings. Her blindness has kept her away from the real world's ugliness and helped her see the light in the books she has read, an individual light.

The girl's story is gradually interlaced with the story of the Sea of Flames, a blue diamond that offers its keeper eternal life, but brings misfortune to the world and to all the people that the keeper loves. Whenever someone gets the Sea of Flames, he/ she becomes powerful, but also a war is unleashed and many people die. She is told the story during a visit to the museum when the guide admits the fact that the stone is well locked in a room. Knowing that according to the legend the stone was made by the Goddess of the Earth for her lover, the God of the Sea, and that the curse will end only when it is given to the sea, the girl asks: "Why not [...] just take the diamond and throw it into the sea?" (Doerr, 2014: 23). Thus, the author builds the girl's portrait and projects a potential action. If Marie-Laure had the stone she would throw it into the sea, which means that the Sea of Flames should get into her hands to have the war concluded, therefore the visit to the museum is an anticipatory moment to show that legend and war interfere.

With the outburst of the war, Marie-Laure's father is entrusted the diamond, to protect it from the Nazis, represented here by Sergeant von Rumpel, a treasure hunter for the Reich. In 1940, when France is invaded, Marie-Laure and her father move to Saint-Malo to her great-uncle Etienne. Monsieur LeBlanc hides the diamond in the model of Saint-Malo made for his daughter, the stone eventually gets into MarieLaure's hands and protects her from the war while her father is arrested and sent to a concentration camp. The evolution of Marie-Laure and her father, as predicted by the story of the Sea of Flames, retells the legend but in modern times. At the same time the legend is a pretext for the economy of the narrative, a mise en abyme symbolically encapsulating the whole novel. Instead of simply mentioning some of the reasons at the back of the war, Doerr uses Sergeant von Rumple who hunts for the magic diamond that can bring the owner, the Reich here or even himself, power, eternal life and riches. 
When the diamond gets to Marie-Laure in Doerr's organization of the events, readers may expect her to be protected and/or to return the stone to the sea. Marie-Laure herself assumes her granduncle's house stands during the bombardment due to the stone. Besides magic, it is obvious that the house resists due to Werner's decision not to give the coordinates that would have made a target of it. The boy protects the beauty of his childhood memory of music and stories.

Anthony Doerr weaves the story of the war around the legend of the Sea of Flames and for the first time hands the powerful stone to an innocent and kind person raised to believe in magic and in science at the same time. His novel demonstrates that each individual can contribute to the wellness of the world and that common people and open-minded children that sapped at the spring of art can make a better world.

Werner's story is presented in parallel - an orphan with a gift to understand and create electric circuits living in Zollverein, a coal-mining town. He finds a radio, repairs it and hears a Frenchman talking about science and broadcasting music. He is fascinated with the lesson and the music which follow him for the rest of his life. Werner is afraid that he might die like his father in the mine and his gift for radio mechanics helps him get a place at the training school for the Nazi military elite. He succeeds in making a directional radio transceiver and is sent to find those who 'illegally' transmit information about the German army. His experience with the front is sickening and traumatizing. He is eventually sent to Saint-Malo and in 1944 he meets Marie-Laure, whom he protects as he recognizes in her the granddaughter of the Frenchman he heard in his childhood. Werner's love for music hinders him from communicating the coordinates of Etienne's house, where the radio is. He disobeys the war orders, with his companion's complicity, to let the source of his childhood joy survive. Werner is puzzled by Marie Laure's broadcasting music and literature, and lets himself be caught by his childhood memories as if he had reached the destination: a return to innocence, a moment when the boy "lives through art".

Doerr shows how apparently insignificant details of the children's lives can mark them and change the course of the events, which may explain his use of meticulous descriptions or the emphasis on items that will become relevant later. The atmosphere in the novel is upheld through the abundant details and adjectives which seem to digress from the course of the main events and relax the atmosphere or soften the impact of the events like an escape from the cruelty and violence of the war. Doerr gradually builds a counter world adrift from the harsh reality, a world where music and fiction underpin the characters' advance through the horrors of the war.

Any shocking event makes the characters retrace the way that led them there and remember and/or analyse the reasons for which they made their choice. Such revisits of the past reiterate details and impressions that the author had carefully 
slipped into the text, which seemed inappropriately minute at the time they happened, but emotionally supportive in time, like landmarks in the characters' quests for themselves. According to the characters' personalities, these details/memories that revisit them function differently. For Marie-Laure they are guidelines in the concrete world that she cannot see but feels and imagines. "Marie-Laure tries to remember everything she knows about the lock and latch on the gate, everything she has felt with her fingers, everything her father would have told her. Iron rod threaded through three rusted loops, old mortise lock with a rusty cam. Would a gunshot break it?" (Doerr 2014: 419). As regards Werner, his memories are recalled to counterbalance his regrets for having chosen the Nazi school showing that sometimes decisions are contextual, punctual, and incomprehensive.

He remembers Frau Elena as she looked early this morning, standing in her nightdress beside the hall lamp, fussing over his bag, all the other children asleep. She seemed lost, dazed, as if she could not absorb how quickly things were changing around her. She said she was proud. She said Werner should do his best. "You're a smart boy," she said. "You'll do well." She kept adjusting and readjusting his collar. When he said, "It's only a week," her eyes filled slowly, as if some internal flood were gradually overwhelming her. (Doerr 2014: 113)

Acting in the war is like acting against himself, while protecting his body. Werner's memories and work help him recreate an inner world to host and protect his mind, being guided by the music he heard when he was a child. Another colleague of his, Volkheimer, spends much of his time listening to music, which counterweights death and the terrifying experience at Schulpforta. The beauty of the two children's minds resists the ugliness of war making of their meeting a reconciliation of the opposite camps, of the products of different spaces and contexts and revealing the importance of childhood education.

Though built like a labyrinth, with a continuous oscillation between France and Germany, between the war as experienced by Werner and the threats reaching Marie-Laure's protective environment, Doerr's novel is a self-reflexive one. The embedded stories, Jules Verne's book that Marie-Laure reads, the legend, the titles of the subchapters, such as "The Simultaneity of Instances", and theories like the one about enthropy are guidelines for the understanding of the novel. The war is associated with randomness and disorder/chaos. When the two children make decisions they live the illusion of being in control of their lives. Paradoxically Werner and the other boys at Schulpforta are told that the war is meant to cancel disorder even in genes, which 
explains the strict selection of the boys. The contrast between the objectives of the war (Doerr 2014: 240), according to Hauptmann, and what the war brought in Europe enhances the idea that enthropy is specific to any system, including the social ones.

"Disorder. You hear the commandant say it. You hear your bunk masters say it. There must be order. Life is chaos, gentlemen. And what we represent is an ordering to that chaos. Even down to the genes. We are ordering the evolution of the species. Winnowing out the inferior, the unruly, the chaff. This is the great project of the Reich, the greatest project human beings have ever embarked upon."

Hauptmann writes on the blackboard. The cadets inscribe the words into their composition books. The entropy of a closed system never decreases. Every process must by law decay. (Doerr 2014: 240)

Besides, the way in which the novel is organized imitates enthropic disorder and suggests people's lack of control. Enthropy can be considered a narrative device Doerr uses to render Europe during the war.

Within this context, characters make decisions meant to help them survive or follow their dreams, yet, despite the initial logic, they face unexpected events and changes that put them in opposite situations and create moments of crisis. Werner wants a safer and better life and he considers his admission to Schulpforta is an opportunity, but he is only used until Hauptmann obtains the transceiver. Then Werner is sent to the front although he has not finished the training period and is not the right age. Mr LeBlanc decides to leave Paris for Saint-Malo, a smaller town of less interest to the forces involved in the war, in his opinion. Yet, Saint-Malo is the place where the treasure hunter von Rumpel finds Mr LeBlanc and arrests him, and also the most affected place because of the bombardment. Frederick, Werner's friend, is sent to Schulpforta by his parents who consider this school an opportunity for his growth and for their social position. He is identified as weaker than the others, beaten and humiliated. His personality, interests and determination not to ask to leave make him return home in a vegetative state he will never recover from. He only reacts when he sees the images of the birds that he used to love so much.

The events seem to be randomly orchestrated from beyond man's will and power. To aesthetically reconcile randomness and reversing situations with the narrative order he follows, Doerr uses the legend of the Sea of Flame, literature and music which create emotion, harmony and develop skills that help the characters cope with the war. Marie-Laure's blindness is compensated by her sharp senses and courage and also by the magic power of the diamond that she holds until the danger passes away. 
As the legend says, the people that she loves die or go through misfortune. Her father is probably dead, Werner commits suicide. Her decision to return the stone to the sea makes it impossible for her to check whether eternal life can be reached. It is also a return to normality as if the stone had launched and maintained the war. Thus the novel itself becomes one of the legends built around the stone, a rewriting of it. Therefore Doerr's novel erected among the remains of a terrifying war is an aesthetic attempt to show that art, innocence, beauty and human feelings can never be buried under the ruins, but they succeed in making mankind go on.

\section{References}

Chopik, W. J. and R. S. Edelstein (2019). Retrospective Memories of Parental Care and Health from Mid- to Late Life. Health Psychology, 38(1), 84-93. (4 November 2019) <http://dx.doi.org/10.1037/hea0000694>.

Danchev, A. (2009). On Art and War and Terror. Edinburgh: Edinburgh University Press.

Doerr, A. (2011). Books, Memory and the Twelve Bright Stars Scratched Across Page 302. NW Book Lovers. (16 May 2018) <https://nwbooklovers.org/2011/01/07/ anthony-doerr-on-books-memory-and-the-twelve-bright-stars-scratchedacross-page-302/>.

Doerr, A. (2014). All the Light We Cannot See. New York: Scribner.

Freud, S. (1995). The Basic Writings of Sigmund Freud (Psychopathology of Everyday Life, the Interpretation of Dreams, and Three Contributions to the Theory of Sex). New York: Modern Library.

Heaney, S. (1995). The Redress of Poetry. London: Faber.

Heaney, S. (1999). Open Ground. Selected Poems. 1966-1996. New York: Farrar, Straus and Giroux.

Lamberti, E. and V. Fortunati. (2009). Memories and Representations of War. Amsterdam and New York: Rodopi.

Murphy, A. (2009). Seamus Heaney. Devon: Northcote House Publishers Ltd. 